\title{
ANALYSIS OF THE PSYCHOLOGICAL CHARACTERISTICS AND ENTREPRENEURIAL INTENTIONS AMONG UNIVERSITY STUDENTS
}

\section{Junaid Ali Sohu1*, Ali Raza Lashari², Israr Ahmed Memon³, Manzoor Ali Brohi ${ }^{4}$, and Asadullah Kehar ${ }^{5}$}

\begin{abstract}
Today's technological development and rapid advancements are increasing day by day, simultaneously the rate of unemployment is also rising, especially in developing economies. In the view of long-term perspective, the global economic cycle has also been affected and is leading towards economic crises. Hence, with the dearth of employment opportunities, the youth in developing economies are inclined towards entrepreneurship and startups. Startup ventures provide them with specific sources of income as well as self-independence and self-sufficiency. Hence, the researcher in this paper attempts to explore the entrepreneurial intentions among university students. It has been observed that the reason behind this inclination is the outstanding potential the university students possess and their ambition to try new things and risk-taking tendencies. Furthermore, the new generation has the ability to develop various variations in businesses. The work is conducted on a Pakistani youth segment from the Quaid-i-Azam University Islamabad, which has a diverse pool of students belonging to various regions of Pakistan. Data analysis and findings demonstrate that the students of Quaid-iAzam University, Islamabad, not only possess a positive attitude toward entrepreneurial intention, but they also face ambiguities and difficulties in taking initiatives. Business assistance is required by them, in the form of financial and moral support, as well as professional guidance for understanding the business background. The study provides some useful insights on the subject and presents future study recommendations and practical implications.
\end{abstract}

Keywords: Entrepreneurial Intention; Locus of Control; Risk Taking Propensity; Self-Confidence; Ambiguity Tolerance; Need for Achievement; Innovativeness.

\footnotetext{
${ }^{1}$ Department of Public Administration, SALU, Khairpur, Pakistan. Email: junaidsohu@ gmail.com

${ }^{2}$ Department of Public Administration, SALU, Khairpur, Pakistan. Email: lashari.aliraza@ gmail.com

${ }^{3}$ Department of Mathematics, SALU, Khairpur, Pakistan. Email: israr.memon@ salu.edu.pk

${ }^{4}$ Department of Management Sciences, BUITEMS, Quetta, Pakistan. Email: manzoor.ali@ buitms.edu.pk

${ }^{5}$ Institute of Computer Science, SALU, Khairpur, Pakistan. Email: asad.kehar@ salu.edu.pk

*Corresponding Author
} 


\section{INTRODUCTION}

Now a days, the fear for ambiguous future because of a long-term economic contraction and world-wide financial crisis are stretching in our societies. Further a rapid change in industrial trend towards the induction of more advanced technologies, downsizing as well as profit maximization and cost control, boosted the unemployment and jobless growth at great extent Park (2017).

In this world the humans remain the active representative towards developments, hence they move towards entrepreneurship intentionally due to increasing unemployment. It indicates that business development is their own choice (Brandt städter \& Lerner, 1999), (Krueger, 2007). This is supported by the theory of planned behavior, which indicates that development of entrepreneurial intention and turning towards its practical implication, is all about the conscious state of mind, by which one intent and convert it into business development (Bird, 1988), (Krueger, Reilly, \& Carsrud, 2000; Lee, Wong, Foo, \& Leung, 2009).

The education is considered as main and independent source to improve entrepreneurship rather than to be a dependent employee. An entrepreneur is considered as an independent owner and boss of his business. Entrepreneurship and creation of new-fangled and innovative businesses, postulates that there is solid connection among education and entrepreneurship (Henry, 2003 ), (Peterman, 2003), (Fayolle, 2006), (Ferreira \& Raposo, 2007), (Raposo M. F., 2008), (Oosterbeek, 2010), (Von Graevenitz, 2010).

Accordingly, to (Kuratko, 2005), "Business education assist in creation of simple and innovative enterprise, and its positive characteristics". Because various information by different scholars, proves that entrepreneurship education plays vital role to enhance student's entrepreneurial intention (Pittaway, 2007), (Nabi et al., 2010).

Entrepreneurial role can be cultured by experimentally and by education. In the previous time a proper and private enterprise learning affects the behavior of university students, in the way of developing inclination of their behavior towards opportunities for entrepreneurship. Different teaching methods were used to motivate students to take decision and recognize their faults, as part of their learning process. Hence, it was simple at the early age of entrepreneurship education to set the students mind for independent business owner (Frank, Korunka, \& Lueger, 2005).

On the other hand, general studies indicates that entrepreneurship education in developmental age of the students has strong and positive impression for thinking towards entrepreneurship (Peterman, 2003). This thought is supported by European union suggestions (Action Plan to 
Promote Entrepreneurship and Competitiveness, European Commission, 2003), which states for the support of business through training, framework from unanticipated instruction to school as a focal objective (Frank, Korunka, \& Lueger, 2005).

Information regarding business qualities, left exceptional effect upon entrepreneurial expectations (the aim for to establish a business). Diverse studies conducted upon graduate and undergraduate students, indicates that various psychological traits, affecting the intent to become entrepreneur from which age is also considered as one trait. So, each age group must be realized particularly regarding creation of enterprise. The explanation of this work is to examine and proceed with activities of mental sizes on the judgment of created organizations around the graduates.

\section{SCOPE OF THE STUDY}

In the modern era of global economic development, the entrepreneurship is proved as a precious constituent (Phillips and Kirchhoff, 1989; Keeble, 1990) due to development of new venture as well as various sources of employment, and also by providing various innovative and tough competition. Now a days entrepreneur proved as helpful agent accompanied with innovative technologies because of productivity will be innovative and enhanced. But such that technology also decrease the employment and manpower (Hindle \& Rushworth, 2000; Kuip \& Verheul, 2004; Fitzsimmons \& Douglas, 2005; Gibb \& Hannon, 2006; Mohar et al., 2007; Johansen et al., 2012). In such way entrepreneurship proved as a good solution of increasing unemployment.

In emerging countries of the world, youth is inspired towards entrepreneurship, by availing various self-employment activities to them, hence the rate of unemployment and poverty is also decreased in such countries (Awogbenle \& Iwuamadi, 2010). In such most of the countries the entrepreneurship is proved as an active element in fast economic and peace development. In recent period the entrepreneurship brings great changes the of advanced countries, because the individuals become extraordinary and prosper as well as they can simply acquire their casual and desired objective, due to their independency and boss of their own business (Fauchart \& Gruber, 2011). Entrepreneurship is also considered as main pillar and agent for the development of innovative products, services as well as various opportunities of employments for the country economy (Formica, 2002; Postigo \& Tamborini, 2002). On the other hand, the entrepreneurship is also proved as good source for the societal development, because when peoples have source of income, they will ultimately develop their societies and maintain discipline in their social life (Carney \& Rayan, 2010). 
In Pakistan, a most of the students specify their future direction for the acceptance for entrepreneurship, as a main career, and desired choice for source of more money. On, the basis of the given benefits and development the inspiration and motivation for the development of entrepreneurship is important. Hence the author tries to investigate the intention among the students as well as an acceptance as their future choice to be entrepreneur.

The upcoming parts of this work will help to identify the students' mental entrepreneurial aspects and entrepreneurial aims, introducing research theories and ensuing structural model. Further segment will depict about the research technique and outcomes. In the last two areas, we talk over our outcomes and limitation, future research recommendation and conclusion.

\section{LITERATURE REVIEW}

\section{Entrepreneurial Intention}

According to Krueger \& Carsrud (1993) that Ajzen's (1991) "theory of planned behavior" (TPB) is proved as an appropriate and theoretical framework assistance to recognize the influence of various personality variables on the development of intentions for entrepreneurship. Theory of Planned Behavior is proved as a best supporter to develop the intent for business. It is because this theory is also used and analyzed by previous researcher through various theoretical framework, and also proved as a good source for the intention development (Armitage \& Conner, 2001), (Krueger, Reilly, \& Carsrud, 2000).

The general principle of the theory of planned behavior given by (Ajzen, 1991) is that when the students develop the intentions, it means they are planning their future activity, (supposing as starting a new venture in near future) is all about their deliberate and willingly activity, which force them to act upon the that intention and shape it in practical, it means their intention drive their behavior towards business. At this stage the students fell an immense need of moral support and a proper guideline to prove as a successful entrepreneur. Such support must be provided them by their educational institutions in the form of their course development and practical implication. Individuals' intentions are shown by their behavior, as it is proved by TPB theory. Most of the time the individuals' intentions are also influenced by some exogenic characteristics (such as, their skills, culture, demographics, social and monetary support) these characters influence the behavior directly as well as indirectly (Shapero and Sokol, 1982). Further the entrepreneurship in previous literature analytically tested by various portions of theory of planned behavior in which self-employment is proved as the marked behavior and best way for the transforming intentions into a practical shape (Kolvereid, 1996a; Krueger et al., 2000; Luthje and Franke, 2003). 
Entrepreneurial intention is the readiness of an individual to run a business, gaining and developing consideration, particularly from a social mental viewpoint (Krueger, 2000); (Shook, 2003); (Edelman, 2010). Entrepreneurial plan is a critical element; it presents the real conduct, in this way furnishing great expectation will impact for business endeavor (Krueger, et al 2000); (Shook, 2003); (Brush, et al 2008). (Thompson, 2009) brought up that there is absence of an agreeable or dependable meaning of and predictable approach to measure singular entrepreneurial expectation.

Different scholars define entrepreneurial intention in different way such as "it is all about knowledge and strong belief to develop or install a new and innovative business or planning about to take initiative of the new business in near future (Thompson, 2009). Further the intention is defined by Bird, (1988) that it is all about the diversion of mind attitude and thinking at the self-employment rather than a dependent employee (Bird, 1988).

Currently the entrepreneurial intention issue proved as the center of the scientific consideration (Abebe, 2012). So that is why the graduates of different institution pay enough attention towards research and actual attitude development towards this topic (Martínez \& Vila, 2007).

Now a days different scholars paying a significant attention and focus on development of entrepreneurial intention and actual conduct. It is done with the assistance of different theories which are proved as enhancing the intention towards entrepreneurship, as theory of TPB, and theory of EV (entrepreneurial event). Scholars also define different factors which influence the individual behavior and entrepreneurial intentions a lot (Shapero \& Sokol, 1982). Choo (2006) said that "the individual responsibility being a businessperson to establish a business is a confusing circumstance of search which has a huge effect on molding entrepreneurial propositions.

According to the research work of (Frank, Korunka, \& Lueger, 2005), that secondary education has drawing thought of the business efforts, instructions and fictional works, these institutions also indicate effects of undertaking training projects. They further said that the optional education is proved as a significant for development of entrepreneurial planning. It is further supported by the work of (Peterman, 2003), that the much more amount of youth is essential at the initial stage to acquire the fundamental learning for entrepreneur and to advertise an uplifting behavior towards business endeavor.

\section{Locus of Control}

As the locus of control is well-defined by various scholars, some of the scholars also called it as a personality variable, which tells us about the expectation of an individual he/she could 
handle the actions in the life (Leone, 2000). Entrepreneurs always wants to have new opportunities. for this purpose, they develop innovativeness attitude, and they believe that they have ability to manage events in their life, or, we can say that they have inner locus of control (Mueller, 2000); (Utsch, 2000). In help to take actions, further (Lathrop \& Smith, 2003) found that there is no substantial impact of the Locus of control because the condition in which support is desired in the study, rather than emergency.

According to (Chiu, 2005) people having external locus of control they are more responsive towards the organization because they expect that their firm atmosphere poses an excessive influence on their activities. It is also supported by the explanation of (Kuip, 2003) Achievement of the goal or objectives is due to their ability rather than fortune or luck or further people efforts.

There are two types of the individual control perception, as it is defined on the basis of the theory of locus of control (Ng, Sorensen, \& Eby, 2006; Shane, Locke, \& Collins, 2003; Zigarmi, Galloway, \& Roberts, 2018). From these two types, individuals possess either inner or external locus of control (Rotter, 1966). The individuals with inner or internal locus of control are possessing the strong power and judgement about the event happen in the near future. It indicates that the peoples with internal locus of control believe that they will be a successful entrepreneur, because they take actions upon work with strong and energetic behavior. On the contrary those peoples who possess external locus of control believe that they can control the outcome of event occur by their actions (Judge, Erez, Bono, \& Thoresen, 2002).

Perceptions of the individuals about the outcomes of their actions either influenced by their decisions or not much more relates to their behavior (Wang, Bowling, \& Eschleman, 2010). It indicates that while the individuals possess intention to become entrepreneur, it will be shaped practically if the individual having the internal locus of control. It will direct the individuals to divert their behavior towards business, gaining of more knowledge, arrangement of financial resources and planning for controlling these activities. At the same time, it is believed that recognition of the opportunities is also greatly influenced by locus of control, as opportunities are considered as objective, where as their process of recognition is considered as subjective (Shane \& Venkataraman, 2000). It can be assumed that one event may be believed as an opportunity by certain individuals but not judge by others as an opportunity.

Scholars imagine that entrepreneur's aspirant inner locus of control will accompanied with a developed intention for entrepreneur as well as for opportunity recognition. For the reason the inner locus of control of a person may be inclined to observe the surrounded environment 
positively as well as choose thought-provoking activities (Judge, Locke, \& Durham, 1997; Wang et al., 2010). On the other hand, individual with keen in entrepreneurs with external locus of control is anticipated to match with lower intention as well as opportunity recognition because individual with external locus of control is more liable to observe negatively their environment and are seen busy in challenging tasks ( $\mathrm{Ng}$ et al., 2006).

Likewise, the study on entrepreneurship by indicating the implication of locus of control as a psychological character of the individuals which influence decision-making process for becoming entrepreneurship.

\section{Propensity to take the Risk}

Keh (2002) He found that the propensity for risk contain the readiness to assign significant resources for use of opportunities or lead the business strategy in a direction where result is highly uncertain. As it is well known that there is always fear of loss for starting of any of business, so keeping oneself ready to that risk on the behalf of attaining a huge profit is considered as propensity to take risk. It is also supported by the (Entrialgo, 2000). Entrepreneurship is historically connected with risk taking, the primary component in separating ambitious people from utilized specialists is the doubt and hazard taken by the previous (Entrialgo, 2000); (Thomas, 2000). Because of a nature, business likewise holds distinctive benefits as financial well-being, profession chances, family relations, enthusiastic state and natural well-being (Erdem, 2001); (Littunen, 2000). Businesspeople are generally reputed to be having a more terrific fondness to go for broke than different aggregations (Cromie, 2000); (Thomas, 2000).

\section{Self-Confidence}

According to the (Lu" thje, 2003) force of approach towards the self-service may be connected to two behavior character (inner locus of control and risk leading propensity) also two features (supposed barriers and maintenance) and some inner components (self-confidence and motivation) also some outer components (supposed stage of learning, support and opportunity) to entrepreneurial preference of individuals.

Entrepreneurs having different characters attempt to develop dimensions in their contributors, which are as; opportunity finding, skills for solving issues, taking risks, conducting venture, becoming an independent employee as well as commitment to work and tasks and teams (Jones-Evans, 2000), so, self-confidence is one and most important character of these. Further 
it is explained by the (Cromie, 2000) that, self-confidence may be proved as a product ratherthan cause of free enterprise.

\section{Tolerance for Ambiguity}

Development in organizational behavior field reveals that organizations might be facilitated by the knowledge management, learning (by internal or external forces) and therefore allow them to handle ambiguity and uncertainty. Increase constantly and vary in response to the technology and market needs (Edmondson, 2002).

Entrepreneurial manager mostly give preference to tolerate ambiguity as compared to traditional managers, it is because that entrepreneurial people face less planned and additional set of uncertain chances and really allow vital duty for decision (Entrialgo, 2000). Threat and doubt are two elements of entrepreneurial temperament, and decisions taken by them are mostly inside events which are original and innovative, (Cromie, 2000).

In general ambiguity can be effectively handled by gaining related knowledge as well as learning or by having an interpretating, and smoothly maintaining the external forces, and responded properly (Zack, 2001).

\section{Need for Achievement}

People having well-constructed needs to accomplish. These individuals' needs are developed around those peoples who requires to develop the result by solving issues themselves as well as construct a specific and focused targets and tries for accomplishment of these focuses by their own efforts. Such people shows improved effect in hard targets and are creative in sense for looking diverse and better approaches to build their performance (Littunen, 2000), (Utsch, 2000). McClelland first recognized that a high need for accomplishment capable a single person to attain an entrepreneurial place and to attain more accomplishment, fulfillment that might be determine from different sorts of position (Entrialgo, 2000); (Stewart, 2003). As it is defined by the (Florin, 2007), that; Improving state of mind towards more accomplishment in learners arriving at more isolated than the outside cause over high evaluations are the most hard assignments.

\section{Innovativeness}

Innovativeness is the one of the entrepreneurial behaviors that demonstrate entrepreneurial direction (Entrialgo, 2000). Drukar stated that; the innovativeness is a major tool of the entrepreneurship. Innovativeness is an organized look for the modifications as chances for fresh markets, goods and ideas (Cromie, 2000); (Utsch, 2000). Further (Stewart, 2003) said that creativity is natural role in entrepreneurship and that is the thing which separates managers 
from entrepreneurs (Utsch, 2000). It is found that there exists a close relationship between innovativeness and business enterprise presentation. (Thomas, 2000) said that innovativeness is also known as a major feature in defining entrepreneurship role. Innovativeness can be defined as "it is the power to initiate some new processes, products, and ideas in an organization" (Hult, 2004).

\section{RESEARCH MODEL}

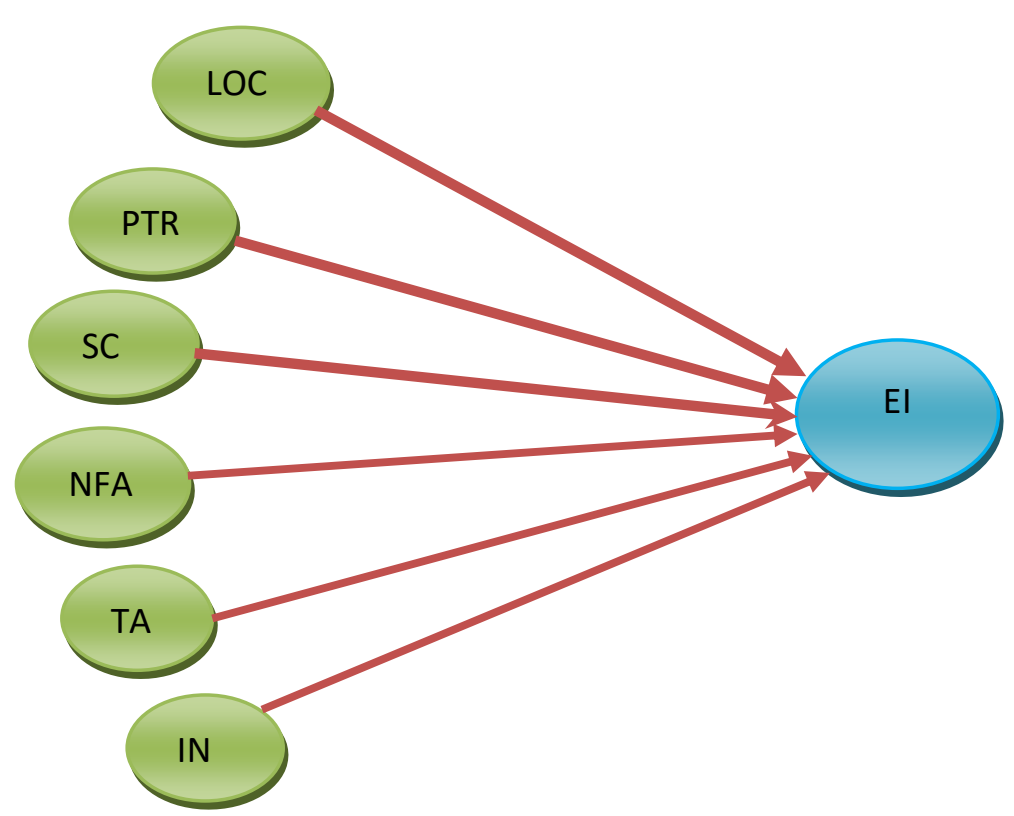

$\boldsymbol{E I}=$ Entrepreneurial Intention $; \boldsymbol{L O C}=$ Locus of Control; $\boldsymbol{P T R}=$ Propensity to take Risk; $\boldsymbol{S C}=$ Self Confidence; $\boldsymbol{N F A}=$ Need for Achievement $; \boldsymbol{T A}=$ Tolerance for ambiguity; $\mathbf{I N}=$ Innovativeness .

\section{RESEARCH HYPOTHESIS}

H1: Locus of Control has a positive and significant relationship with Entrepreneurial Intentions.

H2: Propensity to Take Risk has a significant and positive relationship with Entrepreneurial Intentions.

H3: Self-confidence has a positive and significant relationship with Entrepreneurial Intentions.

H4: Need for achievement has a significant and positive relationship with Entrepreneurial Intentions.

H5: Tolerance to ambiguity has a positive and significant relationship with Entrepreneurial Intentions.

H6: Innovativeness has a significant and positive relationship with Entrepreneurial Intentions. 


\section{METHODOLOGY}

Researcher distributed total 213 surveys questionnaire among the students of Quaid -i-Azam university. The survey instrument was carried from the work of (Linan, 2007) to review entrepreneurial intentions, and by (Koh, 1996) for examining entrepreneurial personality, that operationalize the variables regarding introduction of the Entrepreneurial intentions (Linan, 2007) and Psychological characteristics (Koh, 1996).

The scholar used to fill these instruments survey from the students of the various department, from various disciplines of the Quaid-i-Azam University, out of 213 instruments forms, 197 were resumed back.

The questionnaire comprised of the total of 25 items these were sorted out according to the learning of variables. It is designed as; the first 5 starting questions were associated to the entrepreneurial intention, after that 4 question were allied to the locus of control, then 4 questions were allied with the propensity to take risk, then 3 questions were allied to the selfconfidence, other 4 questions were allied to the need for achievement, next 2 items were connected to the tolerance to ambiguity, and the most recent three items were associated to the innovativeness. Three optional extra items were used, one about the name of the respondents, second about the age of respondents and the third one was regarding the gender of the respondents.

Out of the total sample, 177 respondents were male and 20 were female who filled the questionnaire. The five-point Likert-scale was applied as putting strongly disagree as first choice, Disagree as second, Neither disagree nor agree as third, Agree as fourth and Strongly agree as fifth option.

Researcher has used Descriptive Statistics and the Comparison of Means to calculate the mean values and additional statistics. The Cronbach's Alpha was calculated to find out the reliability and overall similarity and resembling among the variables and the objects of scale used in the research. To study the relationship dependent variable Entrepreneurial Intentions with all the independent variables (Propensity to take risk, Locus of control, Need for achievement, Selfconfidence, Innovativeness and Tolerance to ambiguity) Correlation analysis were used. Regression analysis was used to check the influence of Psychological Characteristics and Entrepreneurial Intentions among university students.

\section{DATA ANALYSIS}

\section{Frequency Distributions}

Frequency tables provide the information about the questions regarding age, education and gender. 
Table 1. Respondents' Gender

\begin{tabular}{ccc}
\hline Gender & Frequency & Percentage \\
\hline Female & 20 & 10.2 \\
\hline Male & 177 & 89.8 \\
\hline Total & 197 & 100.0 \\
\hline
\end{tabular}

Table 1 above shows that total number of respondents were 197, which consist of $177(89.8 \%)$ Male and 20 (10.2\%) Female respondents.

Table 2. Respondents' Age

\begin{tabular}{ccc}
\hline Age & Frequency & Percentage \\
\hline 17-20 Years & 42 & 21.3 \\
\hline 21-23 Years & 143 & 72.6 \\
\hline 24 Years and above & 12 & 6.1 \\
\hline Total & 197 & 100.0 \\
\hline
\end{tabular}

Table 2 shows out of 197 respondents, 40 (21.3\%) individuals were 17-20 years old, 143 (72.6\%) individuals were 21-23 years old, and 12 (6.1\%) individuals were 24 and above years old.

Table 3. Respondents' Education

\begin{tabular}{ccc}
\hline Education & Frequency & Percentage \\
\hline Bachelors & 58 & 29.4 \\
\hline Masters & 138 & 70.1 \\
\hline M.Phil./ PhD & 01 & 0.5 \\
\hline Total & 197 & 100.0
\end{tabular}

Table 3 shows that in 197 respondents, 58 (24.4\%) individuals were from bachelor degree program, and $138(720.1 \%)$ individuals were in master degree program and $1(0.5 \%)$ individual was in M.phil or P.hd students.

Table 4. Descriptive Statistics

\begin{tabular}{lccc}
\hline Description & N & Mean & Std. Deviation \\
\hline Entrepreneurial Intention & 197 & 3.3645 & 0.91169 \\
\hline Locus Of Control & 197 & 3.3261 & 0.62416 \\
\hline Propensity To Take Risk & 197 & 3.2462 & 0.64557 \\
\hline Self-Confidence & 197 & 3.4061 & 0.67914 \\
\hline Need For Achievement & 197 & 3.6142 & 0.71849 \\
\hline Tolerance To Ambiguity & 197 & 3.4442 & 0.81718 \\
\hline Innovativeness & 197 & 3.6582 & 0.73110 \\
\hline
\end{tabular}

Table 4 indicates that independent variable Innovativeness has the highest mean among other variables which proves that students are influenced greatly by Innovativeness and the second 
highest mean is regarding to Need for achievement which has second highest influence on the students. These results indicate that the students want to have a need for achievement as well as they are also inclined towards the innovativeness. Mean the new or fresh entrepreneur are showing their interest to start a business with new ideas or looks different at some extent from the existing business.

Table 5. Correlations

\begin{tabular}{|c|c|c|c|c|c|c|c|}
\hline & EI & LC & PTR & SC & NFA & ITA & INN \\
\hline EI & 1 & $0.163^{*}$ & $0.298 * *$ & $0.380 * *$ & $0.198 * *$ & 0.80 & $0.266^{* *}$ \\
\hline Sig(2-tailed) & & 0.002 & 0.000 & 0.000 & 0.005 & 0.002 & 0.000 \\
\hline $\mathbf{N}$ & 197 & 197 & 197 & 197 & 197 & 197 & 197 \\
\hline LOC & $0.163^{*}$ & 1 & $0.270 * *$ & $0.215^{* *}$ & $0.345 * *$ & $0.236 * *$ & $0.257 * *$ \\
\hline Sig(2-tailed) & 0.002 & & 0.000 & 0.002 & 0.000 & 0.001 & 0.000 \\
\hline $\mathbf{N}$ & 197 & 197 & 197 & 197 & 197 & 197 & 197 \\
\hline PTR & $0.298 * *$ & $0.270 * *$ & 1 & $0.293 * *$ & $0.381 * *$ & $0.440 * *$ & $0.421 * *$ \\
\hline Sig(2-tailed) & 0.000 & 0.000 & & 0.000 & 0.000 & 0.000 & 0.000 \\
\hline $\mathbf{N}$ & 197 & 197 & 197 & 197 & 197 & 197 & 197 \\
\hline SC & $0.380 * *$ & $0.215^{* *}$ & $0.293 * *$ & 1 & $0.394 * *$ & $0.397 * *$ & $0.492 * *$ \\
\hline Sig(2-tailed ) & 0.000 & 0.002 & 0.000 & & 0.000 & 0.000 & 0.000 \\
\hline $\mathbf{N}$ & 197 & 197 & 197 & 197 & 197 & 197 & 197 \\
\hline NFA & $0.198 * *$ & $0.345 * *$ & $0.381 * *$ & $0.394 * *$ & 1 & $0.445^{* *}$ & $0.568 * *$ \\
\hline Sig(2-tailed) & 0.005 & 0.000 & 0.000 & 0.000 & & 0.000 & 0.000 \\
\hline $\mathbf{N}$ & 197 & 197 & 197 & 197 & 197 & 197 & 197 \\
\hline TTA & 0.080 & $0.236 * *$ & $0.440 * *$ & $0.397 * *$ & $0.445^{* *}$ & 1 & $0.470 * *$ \\
\hline Sig(2-tailed) & 0.002 & 0.001 & 0.000 & 0.000 & 0.000 & & 0.000 \\
\hline $\mathbf{N}$ & 197 & 197 & 197 & 197 & 197 & 197 & 197 \\
\hline INN & $0.266 * *$ & $0.257 * *$ & $0.421 * *$ & $0.492 * *$ & $0.568 * *$ & 0.47 & $0 * *$ \\
\hline Sig(2-tailed) & 0.000 & 0.000 & 0.000 & 0.000 & 0.000 & & 0.000 \\
\hline $\mathbf{N}$ & 197 & 197 & 197 & 197 & 197 & 197 & 197 \\
\hline
\end{tabular}

Table 5 indicates that there is highly positive and significant relationship between Entrepreneurial Intention and all independent variables. So, it indicates assistance for showing of the hypothesis, because the scholar assumes that there exists a positive relationship between all independent variables and dependent variable, which is also declared by these results.

Table 6. Reliability Analysis

\begin{tabular}{cc}
\hline Cronbach's Alpha & Reliability Objects \\
\hline .827 & 25 \\
\hline
\end{tabular}


Table 6 demonstrates that the scale possesses 0.827 which is considered as a significant, it is nearer to 1 , which signifies a good reliability of the data, and also signaled towards further continuation of the work.

Table 7. Model Summary

\begin{tabular}{rcccccc}
\hline $\mathbf{R}$ & $\mathbf{R}^{\mathbf{2}}$ & $\begin{array}{c}\text { Std. Error of } \\
\text { the Estimate }\end{array}$ & Durbin Watson & $\begin{array}{c}\text { Adjusted } \mathbf{R} \\
\text { Square }\end{array}$ & $\mathbf{F}$ & Sig: \\
\hline $.465 \mathrm{a}$ & 0.216 & 0.81981 & 1.808 & 0.191 & 8.732 & $0.000 \mathrm{a}$ \\
\hline$a$. & $(D$ V): Entrepreneurial intention. & & \\
b. & $\begin{array}{l}\text { Predictors: (Independent variables), Propensity to take risk, Locus of control, Need for achievement, } \\
\text { Self-confidence, Innovativeness and Tolerance to ambiguity. }\end{array}$
\end{tabular}

Through regression analysis it was found that the $\mathrm{R}$ value (Multiple Correlation Coefficient) is 0.465a which shows a solid relationship between dependent variable (Entrepreneurial intentions) and the independent variables as; (propensity to take risk, Locus of control, need for achievement, self-confidence, innovativeness, and tolerance to ambiguity) the value of $\mathrm{F}$ is (8.732) which is notable at $0.000 \mathrm{a}$ level. The Durbin-Watson value indicates the standard range, that indicates there is not multi-correlation present among the predictors.

Table 8. Coefficients

\begin{tabular}{|l|l|l|l|l|c|}
\hline \multirow{2}{*}{\multicolumn{1}{|c|}{ Description }} & \multicolumn{2}{|c|}{$\begin{array}{c}\text { Unstandardized } \\
\text { Coefficients }\end{array}$} & $\begin{array}{c}\text { Standardize } \\
\text { Coefficients }\end{array}$ & & \\
\cline { 2 - 6 } & \multicolumn{1}{|c|}{$\mathrm{B}$} & Std. error & \multicolumn{1}{|c|}{ Beta } & \multicolumn{1}{c|}{$\mathrm{T}$} & Sig. \\
\hline (Independent variables) & 0.873 & .439 & & 1.989 & 0.048 \\
Locus of control & 0.77 & 0.102 & 0.053 & 0.756 & 0.450 \\
Propensity to take risk & 0.344 & 0.107 & 0.243 & 3.223 & 0.001 \\
Self confidence & 0.459 & 0.102 & 0.342 & 4.492 & 0.000 \\
Need for achievement & 0.002 & 0.106 & 0.001 & 0.018 & 0.986 \\
Tolerance to ambiguity & -0.239 & 0.088 & -0.214 & -2.703 & 0.007 \\
Innovativeness & 0.101 & 0.108 & 0.081 & 0.936 & 0.350 \\
\hline
\end{tabular}

a. Dependent Variable: Entrepreneurial Intention

In the table 7 the value of adjusted $R^{2}$ is $(0.191)$ which shows that the independent variables have $19.1 \%$ variance with Dependent variable. Furthermore, it is the plain from the table that the independent variables Self-confidence and Propensity to take risk have a great force and inclinations towards the Entrepreneurial intention (Dependent variable) with Std: Coefficients 0.243 and 0.342 which are good values at a 0.001 and 0.000 level of significance.

Same way the Standardized Coefficients value for independent variables LOC (0.053), NFA (0.001), TTA (-0.214) and INN (0.081) are significant at $0.450,0.986,0.007,0.350$ respectively. This table also signifies about the hypothesis acceptance, according to the significant value the hypothesis will be accepted, while the value is less than 0.05 . So here the 
values of Locus of control, need for achievement, and innovativeness are more than the defied values, it indicates that null hypothesis is accepted instead of given hypothesis.

It also indicates that the students showing the interest in entrepreneurship, but they are in ambiguous at that stage, if a proper guidance and assistance provided to them than they will fully diverted towards the entrepreneurship.

\section{CONCLUSION}

In Quaid-i-Azam University, students come from all over the country, that is why it is well known for that name. There is great diversity of multiple colors, we can say it as chines bowl, because one can see cultural, social, religious as well lingual diversity there. In this research we had examine that the youth possess the intention about the entrepreneur because if they develop that intention then they will be a perfect entrepreneur in future. Previous studies shows that the characteristics of entrepreneurship are so important features ought to be included into entrepreneurship learning (Neck, 2011); (Jusoh et al., 2011). The researcher has used seven variables in this research out of them, one is Dependent and six are independent variables. (D.V) Entrepreneurial intention $(\mathrm{R}=0.465)$ is greatly affected by Self confidence among the other variables. The relationship is significant at $\mathrm{Beta}=0.342, \mathrm{t}=4.492$, This shows that the students show their intention for the entrepreneurship. And other, propensity to take risk (Ind. V) has the second major effect on the Entrepreneurial intention (D.V). (R=0.465). This relationship is significant at $\mathrm{t}=3.223, \beta=0.243$. This indicates that the student feel a great responsibility for being an entrepreneur, and the research indicates that Innovativeness (Independent Variable) has the largest mean=3.6582 moreover Need for achievement shows the 2nd largest mean=3.6142. The research also indicates that the persons who want to be entrepreneur they should be innovative nature, or they address the self-confidence with friends etc. or they should be eager for achieving their goal.

\section{LIMITATIONS AND FUTURE RECOMMENDATIONS}

The research has been conducted in Quaid-i-Azam University Islamabad which is a multicultural university, so that learning and civilizing conflicts may express obvious advantages to the study field. The scholar was bound to collect the data from the selected institution which is Quaid-i-Azam University. More data can be gathered from different institutions of Pakistan to obtain better results and more generalizability. The selected sample for researcher work was 200 communicator candidates. This indicates a short number of respondents. The researcher can enhance the sample size but trapped because of financial resources and also area of study. The research demonstrates that propensity to take risk, innovativeness, need for achievement 
and self-confidence were used to measure entrepreneurship so these are not enough variable to measure it.

The government or policy maker must provide the moral and financial support to the students at the initial stage of the startup of business. The university authority should provide some practical assistance to the students who possess strong intention for the entrepreneurship, so that they can test their ideas and check either it become fruitful or not. In this way more students will be motivate and more employments opportunities will be available for the jobless peoples. The people will be societal developed oriented. 


\section{REFERENCES}

Ajzen, I. (1991). The theory of planned behavior. . Organisational behavior and human decision processes, 50, , 179-211.

Alen, N. J. (1990). The measurement and antecedents of affective, continuance and normative commitment to the organization,. Journal of Occupational Psychology, 63 (1), , 1-18.

Alper, S. T. (2000). Conflict management, Efficacy, and Performance in Organizational teams. . Personnel Psychology, , 625-642.

Alsam, N., Imran, R., Anwar, M., Hameed, Z., \& Kafayat, A. (2013). The Impact of Work Family Conflict on Turnover Intentions: Empirical Evidence from Pakistan. World Applied Sciences Journal, 24(5),, 628- 633.

Amabile, T. B. (2005). Affect and Creativity at Work. 367-403.

Ayesha, T. U., Akbar, W., \& Shai, S. (2020). Mediating role of emotional stability and selfesteem between mindfulness and psychological wellbeing. International Journal of Psychosocial Rehabilitation, 24(1), 5161-5174.

Ayub, N., AlQurashi, S. M., Al-Yafi, W. A., \& Jehn, K. (2017). Personality traits and conflict management styles in predicting job performance and conflict. . International Journal of Conflict Management.

Awogbenle, A. a. (2010). "Youth unemployment: entrepreneurship development programme as an intervention mechanism", . African Journal of Business Management, Vol. 4 No. $6,831-835$.

Balay, R. (2006). Conflict management strategies of administrators and teachers. . Asian Journal of management Cases, 3(5), , 5-24.

Balay, R. (2007). Predicting conflict management based on organizational commitment and selected demographic variables. Asia Pacific Education Review, 8(2), 321-336.

Becker-Beck, U. ( 2001). Methods for diagnosing interaction strategies: An application to group interaction in conflict situations. . Small Group Research, , 32, 259-282.

Beersma, B. \&. (2005). Conflict's consequences: Effects of social motives on post negotiation creative and convergent group functioning and performance. . Journal of Personality and Social Psychology, 89(3), , 358-374. .

Behfar, K. J. (2011). Conflict in small groups: The meaning and consequences of process conflict. . Small Group Research, 42(2), , 127-176.

Bird, B. (1988). Implementing entrepreneurial ideas: The case for intention. Academy of Management Review, 13(3), , 442-453.

Blau, P. (1964). Exchange and Power in Social Life,. Wiley, New York, NY. 
Boksberger, P. B. (2007). "Multidimensional analysis of perceived risk in commercial air travel”,. Journal of Air Transport Management, Vol. 13 No. 2, , pp. 90-6.

Brandtstädter, J. \&. (1999). Action and self-development: Theory and research through the life span. . Thousand Oaks, CA: Sage.

Caputo, A. M. (2019). Ten years of conflict management research 2007-2017. . International Journal of Conflict Management, 30(1), , 87-110. .

Carney, P. and Rayan, M. (2010), "Measuring firm-level innovation: review of the literature and surveydesign, innovation foundation", Nova UCD Innovation Park, University College Bublin, Belfield, available at: www.innovationfoundation.ie/Irish\%20Innovation\%20Index\%20Background.pdf (accessed August 11, 2013).

Cetin, M. O., \& Hacifazlioglu, O. (2004). Academics' conflict management styles. Dogus University Journal, 5(2), , 155-162.

Chau, P. H.-H. (2007). "Examining customers' trust in online vendors and their dropout decisions: an empirical study", . Electronic Commerce Research and Applications, Vol. 6 No. 2, , pp. 171-82.

Chen, S. a. (2003). "Interpreting dimensions of consumer trust in e-commerce",. Information Technology and Management, Vol. 4 Nos 2-3, , pp. 303-18.

Corritore, C. K. (2003). “On-line trust: concepts, evolving themes, a model”, . International Journal of Human-Computer Studies, Vol. 58 No. 6, , pp. 737-58.

Cox, K. B. (2001). The effects of unit morale and interpersonal relations on conflict in the nursing unit. . Journal of Advanced Nursing, 35 (1), , 7-19.

Currie, D. G. (2017). The Management of workplace conflict: contrasting pathways in the HRM literature, . International journal of management reviews, 19(4), , 492-509.

De Clercq, D. T. (2009). When good conflict gets better and bad conflict becomes worse: the role of social capital in the conflict-innovation relationship, . Journal of the Academy of Marketing Science, 37(3), , 283-297.

Dobkin, A. \&. (2006). Communication in a changing world: An introduction to theory and practice. . New York: McGraw Hill.

E 'thier, J. H. (2006). "B2C web site quality and emotions during online shopping episodes: an empirical study", . Information \& Management, Vol. 43 No. 5, , pp. 627-39.

Fauchart, E. and Gruber, M. (2011), "Darwinians, communitarians, and missionaries: the role of founder identity in entrepreneurship", Academy of Management Journal, Vol. 54 No. 5, pp. 935-957. 
Formica, P. (2002), "Entrepreneurial universities: the value of education in encouraging entrepreneurship", Industry and Higher Education, Vol. 16 No. 3, pp. 167-175.

Fitzsimmons, J. a. (2005). "Entrepreneurial attitudes and entrepreneurial intentions', a crosscultural study of potential entrepreneurs in India, China, Thailand and Australia",. Babson-Kauffman Entrepreneurial Research Conference, Wellesley, MA, June.

Gibb, and Hannon a. (2006). “Towards the entrepreneurial university?”. International Journal of Entrepreneurship Education, Vol. 1 No. 4, , 73-110.

Hussein, A., Al-Mamary, Y., \& Hassan, Y. (2017). Conflict management styles and organizational commitment: the conceptual framework development. International Journal of Research in Management, Science \& Technology, 5(1), , 86-97.

Hindle, K. and Rushworth, S. (2000). Global Entrepreneurship Monitor Australia, . Swinburne University of Technology, Melbourne.

Ilgan, A. (2020). Examining Principals' Conflict Management Styles: A Study of Turkish Administrators. . Bulletin of Education and Research, 42(1), , 1-16.

Jaros, S. H. (2007). Measurement of commitment., Commitment in Organizations: AccumulatedWisdom and New Directions: . New York: Taylor \& Francis, 347- 382.

Johansen, V., Schanke, T. and Clausen, T.H. (2012), "Entrepreneurship education and pupils: attitudes towards entrepreneurs", in Helmchen, T.B. (Ed.), Entrepreneurship-Born, Made and Educated, InTech, European Union, Rijeka, pp. 113-126.

Judge, T. A., Erez, A., Bono, J. E., \& Thoresen, C. J. (2002). Are measures of self-esteem, neuroticism, locus of control, and generalized self-efficacy indicators of a common core construct? . Journal of Personality and Social Psychology, 83(3), 693.

Kassim, M. A. (2014). Conflict Management Styles and Organizational Commitment: A Study among Bank Employees in Penang. . International Journal of Business, Economics and Law, 4(1), , 45-53.

Khosravi, M. \&. (2013). Studying the Relationship between Knowledge Management and Organizational Entrepreneurship (Case Study: Labor and Social Affairs Department of Qom). . Journal of Basic and Applied Scientific Research, , 643-650.

Kolvereid, L. (1996a). Organisational employment versus self employment: reasons for career choice intentions. . Entrepreneurship Theory and Practice 20 (3), , 23-31.

Krueger, N. F. (2000). Competing models of entrepreneurial intentions. . Journal of Business Venturing, 15(5-6), , 411-432.

Kuip, I. a. (2004). "Early development of entrepreneurial qualities: the role of initial education",. International Journal of Entrepreneurship Education, Vol. 2 No. 2,, 203 226. 
Krueger, N. F. (2007). What lies beneath? The experiential essence of entrepreneurial thinking. . Entrepreneurship: Theory and Practice, 31(1), , 123-138.

Lee, L. W. (2009). Entrepreneurial intentions: The influence of organizational and individual factors. Journal of Business Venturing.

Lim, N. (2003). "Consumers' perceived risk: sources versus consequences", . Electronic Commerce Research and Applications, Vol. 2 No. 3, , pp. 216-28.

Lorenzi, P. (2004). Managing for the common good: Prosocial leadership, . Organizational Dynamics, 33, , 282-91. .

Luthje, C., Franke, N.,. (2003). The 'making' of an entrepreneur: testing a model of entrepreneurial intent among engineering students at MIT. $R \& D$ Management 33 (2), , $135-147$.

Marquis, B. L. (2009). Leadership roles and management functions in nursing: Theory and application: . Lippincott Williams \& Wilkins. .

McKibben, L. (2017). Conflict management: importance and implications. British Journal of Nursing, 26(2), , 100-103.

McKibben, L. (2017). Conflict management: importance and implications. . British Journal of Nursing, 26(2), , 100-103.

McKnight, D. K. (2004). "Dispositional trust and distrust distinctions in predicting high-and low-risk internet expert advice site perceptions", . e-Service Journal, Vol. 3 No. 2, , pp. 35-58.

Morris-Rothschild, B. K. (2006). Teachers' conflict management styles: The role of attachment styles and classroom management efficacy. . Journal of school psychology, 44(2), , 105-121.

Mohar, Y., Manjit, S.S. and Kamal, K.J. (2007), "Relationship between psychological characteristics and entrepreneurial inclination: a case study of students at university Tun Abdul Razak (UNITAR)", Journal of Asia Entrepreneurship Sustainability, Vol. 3 No. 2, pp. 23-41.

Park, C. (2017). "A study on effects of entrepreneurship on entrepreneurial intentions. . "Asia Pacific journal of innovation and entrepreneurship, Vol, 11 No.2., 159-170.

Pruitt, D. G. (1998). Handbook of social psychology. In S. T. In D. Gilbert, Social conflict. (pp. 470-503).

Pruitt, D. G. (2014). Some research frontiers in the study of conflict and its resolution. In P. T. Coleman, M. Deutsch, \& E. C. Marcus (Eds.),. The handbook of conflict resolution: Theory and practice. Jossey-Bass/Wiley, 1087-1109. 
Postigo, S.R. and Tamborini, M.F. (2002), "Entrepreneurship education in Argentina: the case of university of San Andres", IntEnt Conference, Universiti Teknologi Malaysia, Kuala Lumpur, July 8-10.

Rahim, M. A. (1983). A measure of styles of handling interpersonal conflict. . Academy of Management Journal, 26 (2), , 368-376. .

Rahim, M. A. (2011). Managing conflict in organizations (4th ed.). New Jersey: Transaction Publishers.

Rahim, M. A. (2017). Managing Conflict in Organizations. Routledge.

Rajan, D. (2013). Impact of nurses turnover on organization performance. . Afro Asian Journal of Social Sciences, 4(4), , 1-18.

Revuelto-Taboada, L. C.-G.-B. (2021). High-Commitment Work Practices and the Social Responsibility Issue: . Interaction and Benefits. Sustainability, 13(2), , 459.

Robinson, C. (2010). When conflict happens: navigating difficult interactions in senior teams - fostering a culture of constructive engagement. . Business Strategy Series, 11(4), , 214-218.

Schulz-Hardt, S., Mojzisch, A., \& Vogelgesang, F. (2008). Dissent as a Facilitator: Individualand Group-Level Effects on Creativity and Performance. In In C. K. W. De Dreu \& M. J. Gelfand (Eds.), The psychology of conflict and conflict management in organizations (pp. 267-288). San Francisco, CA: Jossey-Bass.

Shane, S. L. (2003). Entrepreneurial motivation. . Human Resource Management Review.

Shane, S., \& Venkataraman, S. (2000). The promise of entrepreneurship as a field of research. . Academy of Management Review, 25(1), , 217-226.

Shapero, A. S. (1982). Social dimensions of entrepreneurship. In: Kent, C., Sexton, D., Vesper, C. (Eds.), The Encyclopaedia of Entrepreneurship. Prectice-Hall, Englewood Cliffs.

Shih, H.-A. \& Susanto, E. (2010). Conflict management styles, emotional intelligence, and job performance in public organizations,. International journal of conflict management, 21(2), , 147-168.

Smith, D. a. (2007). "Flow and internet shopping behavior: a conceptual model and research propositions", . Journal of Business Research, Vol. 57 No. 10, , pp. 1199-208.

Theron M., B. N. (2014, ). Managing the Academic Talent void: Investigating factors in Academic Turnover and Retention in South Africa. SA Journal of Industrial Psychology. , 40 (1), 2071- 0763.

Thomas, J. L., Bliese, P. D., \& Jex, S. M. (2005). Interpersonal conflict and organizational commitment: Examining two levels of supervisory support as multilevel moderators. Journal of Applied Social Psychology, 35(11),, 2375-2398. 
Thrikawala, S. (2011). The determinants of entrepreneurial intention among acadamics in Srilanka : International conference on economics and finance research. LACSIT press, singapore, , 4, 454-458.

Tjosvold, D. (2006). Defining conflict and making choices about its management: Lighting the dark side of organizational life. . International Journal of Conflict Management.

Tjosvold, D., Hui, C., \& Law, K. S. (2001). Constructive conflict in China: Cooperative conflict as bridge between east and west. Journal of World Business, 36(2), , 166-183.

Trudel, J. \& Reio Jr., T. G. (2011). Managing workplace incivility: the role of conflict management styles-antecedent or antidote? Human resource development quarterly, 22(4), , 395-423.

Tunio, M. N., Jariko, M. A., Børsen, T., Shaikh, S., Mushtaque, T., \& Brahmi, M. (2021). How Entrepreneurship Sustains Barriers in the Entrepreneurial Process-A Lesson from a Developing Nation. Sustainability, 13(20), 11419.

Van de Vliert, E. E. (1995). Managing conflict with a subordinate and a supervisor: Effectiveness of conglomerated behavior. . Journal of Applied Psychology, 80, , 271281.

Walczuch, R. a. (2004). "Psychological antecedents of institution-based consumer trust in eretailing”, . Information \& Management, Vol. 42 No. 1, , pp. 159-77.

Wasita Boonsathorn. (2007). "Understanding conflict management styles of Thais and Americans in multinational corporations in Thailand",. International Journal of Conflict Management, Vol. 18 Iss 3 , 196 - 221.

Wazir H, J. I. (2020). Moderating Effects of Organizational Commitment on Job Satisfaction and Turnover Intention. Journal of Research in Emerging Markets., 48-57.

Wesley R. Pieters, E. v. (2020). turnover intention: Lecturers at the University of Namibia. . SA Journal of Human Resource Management., 18(0), , 1683-7584.

Wesley R. Pieters, Ebben van Zyl, Petrus Ne. (2020). Testing a MOodel of Turnover Intention: Lecturers at the University of Namibia. SA Journal of Human Resource Management. , 18(0), 1683-7584.

Wu, J.-H. a.-C. (2005). "What drives mobile commerce? An empirical evaluation of the revised technology acceptance model”, . Information \& Management, Vol. 42 No. 5, , pp. 71929.

Zigarmi, D. G. (2018). Work locus of control, motivational regulation, employee work passion, and work intentions: An empirical investigation of an appraisal model. . Journal of Happiness Studies, 19(1), , 231-256.

Zimbardo, P. (2003). Psychology:Coreconcepts(4thed.). Boston: Allyn \& Bacon. 